\title{
Efek penggunaan tepung umbi dan kulit bawang putih (Allium sativum Linn) sebagai feed additive terhadap penampilan produksi ayam petelur
}

\section{Effect of bulb and skin of garlic feeding (Allium sativum Linn) as feed addi- tive on production performance in layer chickens}

\author{
Maria Karolina Deko, Irfan H. Djunaidi *, dan M. Halim Natsir \\ Fakultas Peternakan Universitas Brawijaya Malang \\ Jl. Veteran Malang Kode Pos 65145 Indonesia
}

Submitted: 14 Juli 2018, Accepted: 17 Agustus 2018

\begin{abstract}
ABSTRAK: Penelitian ini bertujuan mengevaluasi pengaruh pemberian tepung umbi dan kulit bawang putih (Allium sativum L.) (TUKBP) sebagai feed additive pada berbagai level pemberian dalam pakan terhadap konsumsi pakan, Hen Day Production (HDP), egg mass, konversi pakan dan Income Over Feed Cost (IOFC) pada ayam petelur. Sebanyak 320 ekor ayam petelur strain Isa Brown produksi PT. Charoen Pokphand umur 30 minggu, dibagi dalam 8 perlakuan dan 4 ulangan setiap ulangan menggunakan 10 ekor ayam. Rancangan percobaan yang digunakan adalah Rancangan Acak Lengkap (RAL). Delapan kelompok perlakuan adalah sebagai berikut: pakan basal + TUKBP 0\% sebagai pakan kontrol negatif (P0), pakan basal + antibiotik virginiamycin $0,015 \%$ sebagai kontrol positif (P1), dan pakan basal + TUKBP 0,25\% (P2), 0,50\% (P3), 0,75\% (P4), 1,00\% (P5), 1,25\% (P6) dan $1,50 \%$ (P7). Data dianalisis menggunakan uji ANOVA, apabila terdapat perbedaan nyata diantara perlakuan maka dilanjutkan dengan uji Jarak Berganda Duncan.Hasil penelitian menunujukkan bahwa pakan dengan penambahan TUKBP dapat memperbaiki penampilan produksi ayam petelur, meskipun belum menyamai pakan dengan penambahan antibiotik. Penggunaan TUKBP hingga level 1,50\% dalam pakan tidak menimbulkan efek negatif bagi ayam petelur. Pemberian TUKBP pada level 1,00\% (P5) mampu menggantikan antibiotik sintetik atau sebagai feed additive organik di dalam pakan ayam petelur.
\end{abstract}

Kata kunci: bawang putih; feed additive; penampilan produksi; ayam petelur.

ABSTRACT: This study aims to evaluate the effect of giving Garlic and Allium sativum (TUKBP) Flour as feed additives on various levels of feeding in feed consumption, Hen Day Production (HDP), egg mass, feed conversion and Income Over Feed Cost (IOFC) in laying hens. A total of 320 laying hens strain Isa Brown produced by PT. Charoen Pokphand aged 30 weeks, divided into 8 treatments and 4 replications each replication using 10 chickens. The experimental design used was a Completely Randomized Design (CRD). Eight treatment groups were as follows: basal feed $+0 \%$ TUKBP as negative control feed (P0), basal feed + virginiamycin antibiotic $0.015 \%$ as positive control (P1), and basal feed + TUKBP $0.25 \%(\mathrm{P} 2), 0,50 \%(\mathrm{P} 3), 0.75 \%(\mathrm{P} 4), 1.00 \%(\mathrm{P} 5), 1.25 \%(\mathrm{P} 6)$ and $1.50 \%(\mathrm{P} 7)$. Data were analyzed using ANOVA test, if there were significant differences between treatments continued with Duncan's Multiple Range test. The results showed that feed with the addition of TUKBP can improve the appearance of laying hens, although it has not matched the feed with the addition of antibiotics. The use of TUKBP to the level of $1.50 \%$ in feed does not cause negative effects for laying hens. Administration of TUKBP at $1.00 \%$ level (P5) is able to replace synthetic antibiotics or as organic additive feeds in laying chicken feed.

Keywords: garlic; feed additive; production performance; laying hens.

*Corresponding Author: irjuna@ub.ac.id

DOI: 10.21776/ub.jiip.2018.028.03.02 


\section{PENDAHULUAN}

Aspek pakan merupakan salah satu faktor utama penentu keberhasilan suatu usaha peternakan unggas, dalam hal ini usaha ayam petelur. Biaya dari pengadaan pakan mencapai $70 \%$ dari total seluruh biaya produksi peternakan. Ketersediaan pakan baik dari segi kualitas maupun kuantitas sangat berpengaruh terhadap performa ayam, produksi, produktivitas serta kualitas dari produk yang dihasilkan ternak tersebut.

Usaha peternakan akan efisien apabila pakan yang tersedia harganya murah dengan kandungan nutrien yang dapat memenuhi kebutuhan ayam petelur. Upaya untuk meningkatkan efisiensi penggunaan pakan adalah dengan menggunakan antibiotik. Penggunaan antibiotik dalam pakan ternak umumnya sebagai alternatif pengobatan ternak dan sebagai imbuhan pakan (feed additive). Penambahan antibiotik sebagaifeed additive tersebut bertujuan memacu pertumbuhan ternak (growth promoter), meningkatkan kesehatan sehingga dapat mengurangi risiko kematian, meningkatkan produksi dan produktivitas, meningkatkan efisiensi penggunaan pakan maupun untuk pemenuhan nutrisi ternak (Widianto, Prayogi, dan Nuryadi, 2015). Namun penggunaan antibiotik, feed additive ataupun hormon pemacu pertumbuhan ternak yang tidak sesuai dengan anjuran dan tidak sesuai dengan dosis yang ditetapkan dapat menyebabkan residu pada produk ternak yang dihasilkan (Bahri, Masbulan, dan Kusumaningsih, 2005).

Antibiotik yang beredar saat ini, pada umumnya berasal dari produk komersial atau sintetis yang aspek keamanannya kurang terjamin. Selain itu, apabila penggunaannya dalam pakan tidak sesuai dengan dosis yang dianjurkan, maka dapat menyebabkan bakteri patogen dalam tubuh ternak akan resisten terhadap antibiotik yang diberikan. Hal ini akan menyebabkan ternak mudah terserang penyakit baik yang bersumber dari pakan, air minum maupun dari lingkungan sekitar ternak hidup. Antibiotik yang sering digunakan dalam pakan unggas antara lain adalah jenis spiramisin, zinc bacitracin, tilosin dan virginiamycin (Casewell, 2003). Penggunaan feed additive atau antibiotik sintetis di Indonesia saat ini sudah dilarang, hal ini sesuai dengan Permentan RI No.14/ PERMENTAN/ PK.350/ 5/ 2017 tentang klasifikasi obat hewan. Residu antibiotik dalam produk ternak dalam hal ini daging dan telur dapat mengancam kesehatan masyarakat. Ancaman tersebut seperti resistensi bakteri, alergi terhadap produk yang dikonsumsi, resistensi terhadap mikroflora usus serta terjadinya keracunan (toksisitas). Selain berbahaya bagi kesehatan, residu juga dapat berpengaruh terhadap lingkungan dan ekonomi (Iwantoro, 2018).

Salah satu cara untuk mengatasi masalah residu antibiotik sintetis dalam produk ternak yang banyak dikembangkan saat ini adalah penggunaan feed additive lokal (organik) atau antibakteri alami. Potensi feed additive yang digunakan dalam penelitian ini adalah tanaman bawang putih (Allium sativum L.) berupa umbi dan kulit bawang.Bawang putih (Allium sativum Linn) merupakan tanaman yang sudah lama dikenal masyarakat sebagai tanaman yang memiliki banyak khasiat, salah satunya sebagai obat dan antibiotik (Saputra, Mangisah, dan Sukamto, 2016).

Kemampuan bawang putih sebagai sumber feed additive dikarenakan kandungan organosulfur yang dapat berfungsi sebagai antibakteri, antijamur dan antioksidan. Kandungan tersebut diantaranya adalah allicin, ajoene, minyak atsiri dan flavonoid. Allicin berperan sebagai antibakteri, antijamur dan antivirus (Salima, 2015). Tanaman bawang putih yang mengandung senyawa organosulfur tersebut, menjadikan tanaman ini dapat dimanfaatkan sebagai antioksidan di dalam tubuh ternak yang mengkonsumsinya. Selain itu, bawang putih juga merupakan salah satu bahan alami yang memiliki efek antimikotik dan 
dapat mendetoksifikasi aflatoksin baik pada pangan maupun pada pakan. Maryam et al. (2003) melaporkan bahwa sebanyak 4\% ekstrak bawang putih ditambahkan dalam pakan ayam petelur yang mengandung aflatoksin dosis rendah $(0,4 \mathrm{mgAflatoxin}$ $\mathrm{B}_{1} / \mathrm{kg}$ bobot hidup) dapat memberikan pengaruh terhadap peningkatan bobot badan, produksi telur dan mengurangi kadar residu aflatoksin pada telur yang dihasilkan. Dampak dari cemaran ini sangat merugikan karena akan menghambat produktivitas dan kesehatan ternak, serta memungkinkan timbulnya foodborne diseases pada masyarakat (Maryam et al., 2003).

Kulit bawang putih juga mengandung senyawa fitokimia seperti alkaloid, kuinon, flavonoid, saponin dan polifenol yang dapat bermanfaat untuk meningkatkan konsumsi pakan, air minum dan protein serta dapat digunakan untuk menghambat pertumbuhan mikroorganisme yang merugikan dalam saluran pencernaan ayam, sehingga pemanfaatan zat makanan oleh ayam dapat optimal dan pertumbuhan akan meningkat (Nuningtyas, 2014). Škerget et al.(2009) menyebutkan bahwa kandungan fitokimia pada kulit bawang lebih tinggi daripada bagian umbinya. Berbagai penelitian telah membuktikan bahwa dengan penambahan tepung kulit bawang pada pakan unggas berpotensi meningkatkan produktivitas ternak dengan harga yang relatif murah.

Adanya beberapa kandungan senyawa aktif pada umbi dan kulit bawang putih seperti yang telah diuraikan di atas, menjadikan tanaman bawang putih sangat potensial digunakan sebagai feed additive untuk menggantikan antibiotik sintetik pada pakan ayam petelur. Penelitian mengenai penggunaan tepung umbi dan kulit bawang putih sebagai feed additive dalam pakan ayam petelur telah dilakukan dengan tujuan memberikan informasi mengenai pengaruhnya terhadap penampilan produksi dari ayam petelur. Pemberian te- pung umbi dan kulit bawang putih dalam pakan dapat memperbaiki penampilan produksi ayam petelur.

\section{MATERI DAN METODE Tempat dan Waktu Penelitian}

Penelitian dilaksanakan di kandang milik peternak ayam petelur yang bertempat di Desa Bacem, Kecamatan Sutojayan, Kabupaten Blitar pada tanggal 12 Februari 2018 - 22 April 2018. Analisis proksimat bahan pakan dilaksanakan di Laboratorium Pakan Ternak Dinas Peternakan dan Perikanan Kabupaten Blitar. Proses pembuatan TUKBP dilakukan di Laboratorium Materia Medica Batu, Malang.

\section{Materi}

Materi penelitian menggunakan 320 ekor ayam petelur strain Isa Brown (umur 30 minggu) dengan koefesien keragaman egg mass sebesar 3,37\%. Pakan yang digunakan adalah pakan dari hasil mencampur sendiri (self mixing). Harga pakan basal adalah Rp. $4.821,34 / \mathrm{kg}$, dengan kandungan nutriennya disajikan pada Tabel 1 . Perhitungan kandungan nutrient pakan basal disesuaikan dengan kandungan nutrien pakan ayam petelur dari Buku Panduan Manajemen Ayam Petelur Komersil HyLine Brown 2014. Additive pakan yang digunakan berupa antibiotik virginiamycin serta tepung umbi dan kulit bawang putih.

\section{Pembuatan Tepung Umbi dan Kulit Bawang Putih (TUKBP)}

Bawang putih yang digunakan adalah Varietas Lumbu Putih yang memiliki kualitas standar, dimana di pasaran dijual dengan harga yang murah namun masih dapat dimanfaatkan, baik sebagai bumbu masakan maupun sebagai bahan obat. Bawang putih diperoleh dari Pasar Gadang Malang dengan harga Rp. 12.000/kg dan biaya transportasi yang dikeluarkan sebesar Rp. 8.000. Proses pembuatan TUKBP dimulai dari pemisahan siung menjadi 
siung tunggal. Siung bawang tunggal diiris atau dicacah menggunakan pisau tanpa mengupas kulitnya.

Bawang beserta kulitnya yang sudah dalam ukuran kecil dikeringkan menggunakan oven pada suhu $50^{\circ} \mathrm{C}$ dan dibiarkan sampai kering atau mudah diremukan ( \pm 4hari). Setelah kering proses selanjutnya adalah bahan dihaluskan atau digiling sampai menjadi tepung yang halus di Laboratorium Materia Medica Batu Malang, dengan biaya sebesar Rp. $5.000 / \mathrm{kg}$. Setiap $1 \mathrm{~kg}$ TUKBP dibutuhkan 2,24 kg bawang putih dalam bentuk segar tanpa dikupas kulitnya.

Tabel 1. Kandungan nutrien pakan basal

\begin{tabular}{lcc}
\hline Nutrien & Perhitungan $^{(1)}$ & Analisis Lab. $^{(2)}$ \\
\hline BK $(\%)$ & 88,38 & 88,78 \\
Abu (\%) & 11,99 & 11,04 \\
PK $(\%)$ & 17,88 & 17,74 \\
LK $(\%)$ & 5,64 & 5,43 \\
SK $(\%)$ & 2,92 & 7,26 \\
Ca $(\%)$ & 4,08 & 4,34 \\
Potal $_{\text {To }}(\%)$ & 0,78 & 0,78 \\
Persedia $_{\text {Ter }}$ & 0,49 & - \\
ME (Kkal/Kg) & 2829,93 & 2853,60 \\
\hline
\end{tabular}

Keterangan:

(1) Hasil perhitungan dengan basis data nutrienpada Buku Panduan Manajemen Ayam Petelur Komersial Hy-Line Brown, 2014

(2) Berdasarkan hasil analisa Lab. Pakan Ternak Dinas Peternakan dan Perikanan Kabupaten Blitar, 2018

\section{Metode}

Metode yang digunakan adalah percobaan lapang (invivo) dengan menggunakan Rancangan Acak Lengkap (RAL) yang terdiri dari 8 perlakuan $(\mathrm{P} 0, \mathrm{P} 1, \mathrm{P} 2, \mathrm{P} 3, \mathrm{P} 4$, $\mathrm{P} 5, \mathrm{P} 6, \mathrm{P} 7)$ dan 4 ulangan (U1, U2, U3, U4). Setiap unit perlakuan terdiri dari 40 ekor ayam dengan masing-masing ulangan terdiri dari 10 ekor ayam periode bertelur.

Level pemberian TUKBP pada pakan basal adalah sebagai berikut:

P0: Pakan Basal (Tanpa Antibiotik)

P1 : Pakan Basal + Virginiamycin 0,015\%

P2: Pakan Basal + TUKBP 0,25\%

P3: Pakan Basal + TUKBP 0,50\%

P4: Pakan Basal + TUKBP 0,75\%

P5 : Pakan Basal + TUKBP 1,00\%

P6: Pakan Basal + TUKBP 1,25\%

P7: Pakan Basal + TUKBP 1,50\%

\section{Tahap Persiapan dan Adaptasi Ternak}

Tahap persiapan meliputi persiapan ternak percobaan, persiapan kandang dan perlengkapan pemeliharaan, serta pengadaan bahan pakan perlakuan dan formulasi pakan. Adaptasi ternak terhadap pakan perlakuan dilakukan selama 1 minggu. Pengambilan data penelitian dimulai pada minggu kedua, setelah tahap adaptasi sampai pada akhir penelitian.

\section{Tahap Perlakuan dan Pengukuran Pa- rameter}

Tahap perlakuan dilaksanakan selama 10 minggu mulai dari tahap adaptasi sampai akhir penelitian. Pakan diberikan sebanyak $125 \mathrm{~g} / \mathrm{ekor} / \mathrm{hari}$ yang diberikan 2 kali sehari yaitu pada pagi hari pukul 07.00 sebanyak $70 \%$ dan sisanya diberikan pada siang hari pukul 13.30. Air minum diberikan secara tidak terbatas (ad libitum). 
Pengambilan telur dilakukan pada sore hari setelah pemberian pakan selama masa pemeliharaan. Telur ditata pada egg tray yang sudah diberi kode berdasarkan perlakuan dan ulangan. Selanjutnya dilakukan penimbangan telur untuk mendapatkan data berat telur pada setiap perlakuan dan ulangan serta dirata-ratakan sampai selesai penelitian. Pengukuran konsumsi pakan dilakukan dengan cara menimbang pakan yang diberikan pada hari pertama lalu dikurangi dengan sisa pakan yang diambil dan ditimbang pada hari kedua sebelum pemberian pakan hari kedua dilakukan. Hasil penimbangan pakan yang dikonsumsi maupun sisa pakan setiap perlakuan dan ulangan dirata-ratakan sampai akhir penelitian.

Variabel yang diamati dalam penelitian adalah sebagai berikut (1) Konsumsi pakan harian (gram/ekor/hari) diukur dari selisih jumlah pakan yang diberi pada awal minggu dengan sisa pada akhir minggu, (2) Produksi telur harian (HDP (\%)) dihitung berdasarkan jumlah telur yang diproduksi selama penelitian dibagi dengan jumlah ayam yang ada pada waktu tersebut dikali 100\%, (3) Masa telur (egg mass) (gram/ekor/hari) diperoleh dari penimbangan bobot telur yang dihasilkan oleh setiap ekor ayam pada setiap harinya selama penelitian kemudian dijumlahkan selama periode peneluran, (4) Konversi Pakan (Feed Conversion Ratio)dihitung dengan membandingkan jumlah pakan yang dikonsumsi dengan massa telur selama penelitian, (5)Income Over Feed $\operatorname{Cost}(\mathrm{Rp} / \mathrm{kg}$ telur $)$ dihitung dengan cara mengurangi pendapatan dari hasil penjualan telur $(\mathrm{Rp} / \mathrm{kg})$ dengan total biaya yang dikeluarkan untuk pakan selama periode penelitian $(\mathrm{Rp} / \mathrm{kg})$. Semua data dianalisis varians (ANOVA) dan jika berbeda nyata diuji lanjut dengan uji Jarak Berganda Duncan's (Duncan's Multiple Range Test).

\section{HASIL DAN PEMBAHASAN Konsumsi Pakan Harian}

Data rerata konsumsi pakan ayam petelur periode bertelur yang diberi pakan tanpa TUKBP dan menggunakan berbagai level TUKBP, disajikan pada Tabel 2. Berdasarkan hasil analisis statistik menunjukkan bahwa penggunaan TUKBP dalam pakan ayam petelur berpengaruh sangat nyata $(\mathrm{P}<0,01)$ terhadap rataan konsumsi pakan harian.

Pakan yang dikonsumsi oleh ternak ayam petelur pada setiap perlakuan mengalami peningkatan. Berdasarkan DMRT konsumsi pakan pada P0 lebih rendah daripada P5 dan P6 tetapi tidak berbeda nyata dengan P1, P2, P3, P4 dan P7. Pakan perlakuan kontrol positif (P1) dengan penambahan antibiotik secara statistik menunjukkan hasil yang sama dengan pakan perlakuan penambahan TUKBP mulai dari level $0,50 \%(\mathrm{P} 3)$ hingga pada level tertinggi yaitu $1,50 \%$ (P7). Rata-rata konsumsi pakan paling tinggi terdapat pada level pemberian TUKBP sebanyak 1,00\% (P5) dan 1,25\% (P6). Keadaan ini mengindikasikan bahwa pakan dengan penambahan TUKBP memiliki palatabilitas yang baik.

Penambahan TUKBP pada pakan sebanyak $1,00 \%$ dan 1,25\%dapat meningkatkan konsumsi pakan ayam petelur. Peningkatan pakan tersebut secara umum menyebabkan terjadinya peningkatan protein dan zat nutrisi lain yang terkonsumsi. Banyaknya zat nutrisi yang masuk dalam tubuh ternak dan terserap dengan baik akan digunakan untuk memenuhi kebutuhan maintenance tubuh, kebutuhan untuk bertumbuh dan kebutuhan untuk berproduksi. Penyerapan pakan yang baik terjadi karena kesehatan saluran pencernaan ayam. Hal ini disebabkan karena adanya senyawa fitokimia pada umbi dan kulit bawang putih yang berperan sebagai antibakteri dan antioksidan yang mampu meningkatkan kesehatan ayam petelur, terutama pada saluran pencernaan. Kandungan fitokimia yang terdapat dalam tanaman bawang putih 
dapat meningkatkan kesehatan pada saluran pencernaan (Nuningtyas, 2014).

Tabel 2. Pengaruh penambahan Tepung Umbi dan Kulit Bawang Putih (TUKBP) terhadap performa Ayam Petelur

\begin{tabular}{cccccc}
\hline \multirow{2}{*}{ Perlakuan } & \multicolumn{5}{c}{ Variabel yang diamati } \\
\cline { 2 - 6 } & $\begin{array}{c}\text { Konsumsi } \\
(\mathrm{g} / \text { ekor) }\end{array}$ & HDP $(\%)^{*}$ & $\begin{array}{c}\text { Eggmass } \\
(\mathrm{g})^{*}\end{array}$ & $\begin{array}{c}\text { Konversi } \\
\text { Pakan* }^{*}\end{array}$ & $\begin{array}{c}\text { IOFC } \\
(\text { Rp/butir)* }\end{array}$ \\
\hline P0 & $105,60 \pm 1,27^{\mathrm{a}}$ & $75,75 \pm 0,27^{\mathrm{a}}$ & $44,11 \pm 0,12^{\mathrm{a}}$ & $2,41 \pm 0,03^{\mathrm{e}}$ & $328,89 \pm 7,80^{\mathrm{a}}$ \\
P1 & $106,48 \pm 1,43^{\mathrm{ab}}$ & $87,82 \pm 0,73^{\mathrm{e}}$ & $54,17 \pm 0,76^{\mathrm{f}}$ & $1,97 \pm 0,01^{\mathrm{a}}$ & $506,84 \pm 7,85^{\mathrm{f}}$ \\
P2 & $105,55 \pm 1,22^{\mathrm{a}}$ & $76,59 \pm 0,92^{\mathrm{ab}}$ & $44,75 \pm 0,80^{\mathrm{a}}$ & $2,37 \pm 0,02^{\mathrm{d}}$ & $334,41 \pm 9,28^{\mathrm{a}}$ \\
P3 & $107,36 \pm 1,69^{\mathrm{ab}}$ & $77,02 \pm 0,65^{\mathrm{b}}$ & $45,73 \pm 0,40^{\mathrm{b}}$ & $2,36 \pm 0,03^{\mathrm{d}}$ & $337,33 \pm 4,87^{\mathrm{a}}$ \\
P4 & $108,38 \pm 1,25^{\mathrm{ab}}$ & $82,62 \pm 0,79^{\mathrm{c}}$ & $50,63 \pm 0,55^{\mathrm{d}}$ & $2,14 \pm 0,02^{\mathrm{c}}$ & $416,39 \pm 7,99^{\mathrm{d}}$ \\
P5 & $109,61 \pm 1,92^{\mathrm{b}}$ & $85,20 \pm 0,91^{\mathrm{d}}$ & $52,23 \pm 0,61^{\mathrm{e}}$ & $2,10 \pm 0,01^{\mathrm{b}}$ & $433,19 \pm 3,42^{\mathrm{e}}$ \\
P6 & $109,02 \pm 1,70^{\mathrm{b}}$ & $83,69 \pm 0,90^{\mathrm{c}}$ & $50,24 \pm 0,08^{\mathrm{cd}}$ & $2,17 \pm 0,03^{\mathrm{c}}$ & $392,39 \pm 8,10^{\mathrm{c}}$ \\
P7 & $107,86 \pm 1,42^{\mathrm{ab}}$ & $83,13 \pm 0,51^{\mathrm{c}}$ & $49,48 \pm 0,30^{\mathrm{c}}$ & $2,18 \pm 0,03^{\mathrm{c}}$ & $377,37 \pm 7,97^{\mathrm{b}}$ \\
\hline
\end{tabular}

Keterangan: *) Superskrip yang berbeda pada kolom yang sama menunjukkan perbedaan yang sangat nyata $(\mathrm{P}<0,01)$.

Hasil rerata konsumsi pakan dalam penelitian ini menunjukkan bahwa ayam petelur pada umur 31-40 minggu periode bertelur, mampu mengkonsumsi pakan sebanyak 105,55 - 109,61 gram/ekor/hari. Konsumsi pakan yang dicapai dalam penelitian ini sudah menyamai rata-rata konsumsi pakan ayam petelur yang terdapat dalam Buku Panduan Manajemen Ayam Petelur Komersil Hy-Line Brown (2018) yakni sebesar 105-112 g/ekor/hari. Namun rerata konsumsi pakan tersebut belum mencapai rata-rata tertinggi konsumsi pakan sesuai dengan yang direkomendasikan, sehingga hal tersebut dapat mempengaruhi produksi telur maupun pada massa telur (egg mass) yang dihasilkan. Hal ini disebabkan oleh karena suhu lingkungan selama penelitian mencapai $29^{\circ} \mathrm{C}$, dimana suhu tersebut terlalu tinggi daripada suhu lingkungan atau suhu nyaman yang dibutuhkan ayam petelur yaitu 18$23,9^{\circ} \mathrm{C}$ (Tamzil, 2014). Ayam petelur pada kondisi suhu lingkungan yang tinggi akan mengalami peningkatan frekuensi painting, konsumsi air minum serta terjadi penurunan konsumsi pakan, yang selanjutnya akan mempengaruhi pertumbuhan dan produksi telur serta kualitas telur. Suhu lingkungan yang tinggi juga akan mempengaruhi sintesis, stabilitas dan aktivitas enzim dalam tubuh ternak, sehingga ternak yang dipelihara diatas suhu nyaman akan mengalami perubahan fisiologis yang berdampak pada produksi dan produktivitas dari ternak (Mushawwir dan Latipudin, 2011).

Suprijatna dan Natawihardja (2014) menjelaskan bahwa banyak sedikitnya pakan yang dikonsumsi ternak tergantung pada kualitas bahan pakan yang dipergunakan untuk menyusun pakan, keserasian komposisi pakan dan nilai nutrisinya sesuai dengan kebutuhan untuk pertumbuhan dan produksi yang optimal.Selanjutnya, Wulandari (2012) menyatakan bahwa terdapat beberapa faktor yang mempengaruhi konsumsi pakan antara lain suhu lingkungan, kondisi ternak, imbangan Energi Metabolisme (EM), kandungan Serat Kasar (SK) pakan, status fisiologis dan umur ternak. Pemberian TUKBP pada pakan ayam petelur sampai pada level 1,50\% tidak menimbulkan efek negatif bagi ayam petelur. Hal tersebut menegaskan bahwa TUKBP merupakan salah satu bahan feed additive organik yang dapat direspon baik oleh ternak ayam petelur. 


\section{Hen Day Production (HDP)}

Hasil analisis ragam menunjukkan bahwa pakan perlakuan yang diterapkan, secara statistik berpengaruh sangat nyata $(\mathrm{P}<0,01)$ terhadap HDP (Tabel 2.). Hasil uji Jarak Berganda Duncan's menunjukkan bahwa perbedaan HDP sangat nyata $(\mathrm{P}<0,01)$ antara pakan kontrol negatif $(\mathrm{P} 0)$ dan $\mathrm{P} 2$, dengan pakan kontrol positif (P1) dan pakan dengan penambahan TUKBP (P3, P4, P5, P6 dan P7). HDP pada ayam yang mendapat pakan tanpa antibiotik dan tanpa penambahan TUKBP atau perlakuan kontrol negatif $(\mathrm{P} 0)$ menunjukkan rerata produksi telur yang rendah yaitu $75,75 \pm$ 0,27 . Rerata HDP tertinggi dicapai oleh ayam yang diberi pakan mengandung antibiotik virginiamycin sebagai kontrol positif (P1) yaitu sebesar $87,82 \pm 0,73$. Selanjutnya, HDP mulai mengalami peningkatan pada perlakuan dengan penambahan TUKBP sebanyak 0,50\% (P3), 0,75\% (P4), $1,00 \%$ (P5) dan HDP menurun pada P6 dan P7.

Hal ini mengindikasikan bahwa pakan yang diberikan ke ternak ayam tanpa penambahan antibiotik dapat menghasilkan produksi telur yang rendah dibandingkan dengan ternak yang mendapat pakan dengan penambahan antibiotik. Keadaan ini diduga karena kurangnya asupan zat non nutrisi seperti yang terdapat dalam TUKBP (antioksidan dan flavonoid) dan antibiotik yg tidak terkonsumsi oleh ternak dalam menjaga kondisi saluran pencernaan ayam yang mengakibatkan rendahnya proses penyerapan nutrisi dan berdampak pada produksi yang dihasilkan. Selain itu, apabila dilihat dari konsumsi pakan pada P0 yang lebih rendah secara umum menyebabkan rendahnya konsumsi protein sehingga dapat menurunkan sintesis protein, disfungsi endokrin, berkurangnya kapasitas antioksidan, serta terganggunya keseimbangan kalsium dan fosfor dalam darah yang berdampak pada penurunan produksi telur (Ma et al., 2014).
Tabel 2 dapat dilihat bahwa pakan yang dicampur dengan TUKBP dan memberi respon paling baik adalah pada perlakuan P5 $(1,00 \%)$ bila dibandingkan dengan pemberian TUKBP pada perlakuan P2, P3, P4, P6 dan P7. Hal ini dikarenakan, konsumsi pakan pada P5 lebih tinggi dibandingkan dengan perlakuan lainnya. Konsumsi pakan yang meningkat menyebabkan semakin banyak kosentrasi bioaktif dalam TUKBP yang dikonsumsi oleh ternak. Skerget et al. (2009) yang menyatakan bahwa jumlah pemberian tepung kulit bawang dalam pakan ternak akan menentukan jumlah antioksidan dan antibakteri yang terkonsumsi oleh ternak.

Adanya peningkatan antioksidan, flavonoid dan antibakteri dalam pakan akibat penambahan TUKBP dapat menjaga kondisi mikroflora di dalam saluran pencernaan ayam. Penyerapan nutrien yang efektif pada saluran pencernaan yang sehat, akan berpengaruh pada peningkatan kecernaan protein kasar pakan dan secara tidak langsung dapat berpengaruh terhadap prosuksi telur. Hal ini sejalan dengan pendapat Sukrayana et al. (2016) yang menyatakan bahwa kecernaan dapat dipengaruhi oleh tingkat pemberian pakan, jenis pakan, spesies ternak, cara pengolahan pakan dan kesehatan saluran pencernaan.Adanya kandungan zat nutrisi dan non nutrisi (fitokimia) pada TUKBP menunjukkan bahwa tanaman bawang putih beserta limbahnya berpotensi untuk digunakan sebagai feed additive organik dalam pakan ayam petelur.

\section{Masa Telur (Egg Mass)}

Berdasarkan hasil analisis ragam (Tabel 2) menunjukkan bahwa penambahan TUKBP dalam pakan ayam petelur memberikan pengaruh yang sangat nyata $(\mathrm{P}<0,01)$. Hasil uji Jarak Berganda Duncan's menunjukkan bahwa pakan tanpa penambahan antibiotik ataupun TUKBP (P0) memberikan hasil yang lebih rendah dibandingkan dengan pakan yang dit- 
ambahkan antibiotik virginiamycin atau ditambahkan TUKBP. Pakan dengan penambahan antibiotik (P1) memberikan hasil egg mass yang lebih tinggi yaitu54,17 $\pm 0,76$ diikuti dengan pakan perlakuan TUKBP $1,00 \% \quad$ (P5) yaitu $52,23 \pm 0,61$.

Egg mass pada pakan dengan penambahan TUKBP $0,75 \%$ (P4) memberikan hasil yang sama dengan pakan perlakuan yang ditambahkan TUKBP sebanyak $1,25 \%$ (P6). Tinggi rendahnya nilai egg mass pada pakan perlakuan dengan penambahan antibiotik dan pakan perlakuan dengan penambahan TUKBP dalam penelitian ini dipengaruhi oleh nilai HDP dan berat telur yang diperoleh selama penelitian. Hal ini sejalan dengan pendapat Widjastuti dan Kartasudjana (2006) yang menyatakan bahwa jika salah satu atau kedua faktor (HDP dan berat telur) semakin tinggi maka massa telur juga semakin meningkat dan sebaliknya.

\section{Konversi Pakan}

Konversi pakan (Feed Conversion Ratio) merupakan salah satu tolak ukur untuk mengetahui kualitas dari pakan yang diberikan kepada ternak dalam memenuhi gizi yang dibutuhkan. Konversi pakan yang diperoleh dari perbandingan antara jumlah pakan yang dikonsumsi dengan massa telur selama penelitian. Semakin tinggi nilai konversi pakan, berarti semakin buruk kualitas nilai gizi dari pakan tersebut.

Berdasarkan analisis statistik menunjukkan bahwa pemberian TUKBP pada pakan ayam petelur berpengaruh sangat nyata $(\mathrm{P}<0,01)$ terhadap konversi pakan. Hasil dari uji Jarak Berganda Duncan's menunujukkan bahwa konversi pakan paling baik adalah pada perlakuan pakan dengan penambahan antibiotik (P1) dengan

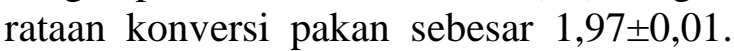
Selanjutnya rataan konversi pakan yang paling rendah diikuti pada pakan dengan penambahan TUKBP pada level 1,00\% (P5). Pakan dengan panambahan TUKBP pada level $0,75 \%$ (P4), 1,25\% (P6) dan $1,50 \%$ (P7) memberikan hasil yang tidak berbeda nyata $(\mathrm{P}<0,01)$. Sedangkan pada pakan perlakuan kontrol negatif atau pakan tanpa penambahan TUKBP dan antibiotik (P0) menghasilkan konversi pakan yang paling tinggi yaitu $2,41 \pm 0,03$. Hal ini menandakan bahwa pakan yang diberikan tidak terserap dengan baik dalam tubuh ayam. Menurut Lokapirnasari dan Soewarno (2011), semakin tinggi FCR maka akan semakin buruk, artinya penggunaan pakan tersebut kurang ekonomis. Konversi pakan ayam petelur berkisar antara 2,1-2,3. Perhitungan konversipakan dimaksudkan untuk mengetahui kemampuan ayam dalam mengubah pakan yang dikonsumsi menjadi telur dan melihat respon ayam terhadap kualitas pakan yangdiberikan (Lokapirnasari dan Soewarno, 2011).

\section{Income Over Feed Cost (IOFC)}

Nilai IOFC merupakan salah satu indikator yang dapat memperlihatkan suatu usaha peternakan mendapatkan keuntungan atau tidak. Berdasarkan Tabel 2 dapat dilihat bahwa rataan IOFC ayam petelur selama penelitian adalah 390,85 dengan kisaran 328,89 sampai dengan 506,84. Hasil analisis keragaman menunjukkan bahwa penambahan TUKBP dalam pakan terhadap IOFC ayam petelur berpengaruh sangat nyata $(\mathrm{P}<0,01)$. Nilai IOFC terendah terdapat pada perlakuan $\mathrm{P} 1$ (pakan basal tanpa penambahan antibiotik dan TUKBP) yaitu sebesar $328,89 \pm 7,80$, diikuti P2 $(334,41 \pm 9,28), \quad$ P3 $\quad(337,33 \pm 4,87), \quad$ P7 $(377,37 \pm 7,97), \quad$ P6 $\quad(392,39 \pm 8,10), \quad$ P4 $(416,39 \pm 7,99)$ dan P5 $(433,19 \pm 3,42)$. Sedangkan IOFC tertinggi terdapat pada perlakuan P1 (pakan basal dengan penambahan antibiotik virginiamycin) sebesar $506,84 \pm 7,85$.

Berdasarkan Uji Jarak Berganda Duncan's biaya pakan pada P0 sama dengan biaya pakan pada $\mathrm{P} 2$ dan $\mathrm{P} 3$, dan terdapat perbedaan yang sangat nyata antara $\mathrm{P} 1, \mathrm{P} 4$, P5, P6 dan P7. Tabel 2 menunjukkan bah- 
wa pemberian TUKBP mulai dari $0,25 \%$ (P2) sampai pada level 1,00\% (P5) dalam pakan maka semakin tinggi pula keuntungan yang diperoleh. Perlakuan dengan penambahan TUKBP sebanyak 1,25\% (P6) dan $1,50 \%$ (P7) mulai menunjukkan keuntungan yang diperoleh menurun. Hal ini diduga karena HDP pada P6 dan P7 menurun sedangkan rata-rata konsumsinya sama dengan P1, P3, P4 dan P5. Biaya pakan P0 lebih rendah (Rp. 4612,12/kg) karena harga pakan tersebut lebih murah dan tidak ditambahkan antibiotik serta memiliki konsumsi pakan yang rendah sehingga harganya lebih murah dibandingkan dengan pakan perlakuan lainnya. Harga pakan paling tinggi adalah pada P7 yaitu sebesar Rp. 4988,12/kg. Hal ini dikarenakan konsumsi pakan serta harga dari TUKBP yang semakin meningkat pada setiap perlakuan. Ardiansyah, Tantalo, dan Nova (2013) menyatakan bahwa IOFC sangat dipengaruhi oleh konsumsi pakan, bobot telur, harga pakan, dan harga jual produk ternak. Nilai IOFC akan meningkat apabila nilai konversi menurun dan apabila nilai konversi ransum meningkat maka IOFC akan menurun. Selanjutnya Prahadiet al, (2015) menjelaskan nilai IOFC selain dipengaruhi oleh konsumsi dan HDP, juga dipengaruhi oleh harga telur di pasaran yang mana nilai IOFC didapat dari produksi telur dikalikan dengan harga telur dikurangi dengan konsumsi dikalikan dengan harga pakan.

\section{KESIMPULAN}

Pemberian TUKBP di dalam pakan ayam petelur dapat memperbaiki penampilan produksi ayam petelur, meskipun belum menyamai pakan dengan penambahan antibiotik. Namun, untuk menghindari terjadinya residu antibiotik sintetik pada produk ternak, maka penambahan TUKBP sampai pada level $1,50 \%$ dapat digunakan dalam pakan sebagai sumber feed additiveorganik untuk meningkatkan penampilan produksi ayam petelur. Penambahan
TUKBP dalam pakan sebesar $1,00 \%$ memberikan efek terbaik terhadap penampilan produksi ayam petelur.

\section{DAFTAR PUSTAKA}

Ardiansyah, F., Tantalo, S., dan Nova, K. 2013. Perbandingan performa dua strain ayam jantan tipe medium yang diberi ransum komersial broiler. Jurnal Ilmiah Peternakan Terpadu, 1(1):158-163.

Bahri, S., Masbulan, E., dan Kusumaningsih, A. 2005. Proses praproduksi sebagai faktor penting dalam menghasilkan produk ternak yang aman untuk manusia. Jurnal Litbang Pertanian, 24(1):27-35.

Casewell, M. 2003. The European ban on growth-promoting antibiotics and emerging consequences for human and animal health. Journal of Antimicrobial Chemotherapy, 52(2: 159-161.

Hy-Line. 2014. Panduan Manajemen: Ayam Petelur Komersial Hy-Line Brown. Hy-Line International EggCel. Diakses Juli 30, 2017, dari https://www.hyline.com/userdocs/p ages/BRN_COM_BAH.pdf.

Iwantoro, S. 2018. Study of Antibiotics Residue on Poultry Produscts in Indonesia. Jurnal Ilmu Produksi Dan Teknologi Hasil Peternakan, 5(1): 29-33.

Lokapirnasari, W. P., dan Soewarno, Y. D. 2011. Potensi Crude Spirulina Terhadap Protein Effisiensi Rasio pada Ayam Petelur Potency of Crude Spirulina on Protein Efficiency Ratio in Laying Hen. Jurnal Ilmiah Kedokteran Hewan Vol, 2(1):5-8. 
Ma, X., Lin, Y., Zhang, H., Chen, W., Wang, S., Ruan, D., and Jiang, Z. 2014. Heat stress impairs the nutritional metabolism and reduces the productivity of egg-laying ducks. Animal Reproduction Science, 145(3-4):182-190.

Maryam, R., Sani. Y., Juariah., S., Firmansyah. R., dan Miharja. 2003. Efektivitas Ekstrak Bawang Putih (Allium Sativum Linn) dalam Penanggulangan Aflatoksikosis Pada Ayam Petelur. JITV. 8(4):239-246.

Mushawwir, A., dan Latipudin, D. 2011. Beberapa Parameter Biokimia Darah Ayam Ras Petelur Fase Grower dan Layer dalam Lingkungan "Upper Zonathermoneutral." Jurnal Peternakan Indonesia (Indonesian Journal of Animal Science), 13(3): 191-198.

Nuningtyas, Y. F. 2014. Pengaruh penambahan tepung bawang putih (Allium sativum) sebagai aditif terhadap penampilan produksi ayam pedaging. Journal of Tropical Animal Production, 15(1): 65-73.

Prahadi, J.A., E. Widodo., dan I.H. Djunaidi. 2015. Pengaruh Penambahan Sari Belimbing Wuluh (Averrhoa blimbi L.) Sebagai Acidifier Dalam Pakan Terhadap Penampilan Produksi Ayam Petelur. $J$. Nutrisi Ternak. 1(1):10-18.

Salima, J. 2015. Antibacterial Activity Of Garlic (Allium sativum 1.). Jurnal Majority, 4(2):30-39.

Saputra, Y. A., Mangisah, I., dan Sukamto, B. 2016. Pengaruh penambahan tepung kulit bawang terhadap kecernaan protein kasar pakan, pertambahan bobot badan dan persen- tase karkas itik Mojosari. Jurnal Ilmu-Ilmu Peternakan, 26(1):2936.

Škerget, M., Majhenič, L., Bezjak, M., and Knez, Ž. 2009. Antioxidant, radical scavenging and antimicrobial activities of red onion (Allium cepa L) skin and edible part extracts. Chemical and Biochemical Engineering Quarterly, 23(4):435-444.

Sukrayana, Y., Atmomarsono, U., Yunianto, V. D., dan Supriyatna, E. 2016. Improvement of crude protein and crude fiber digestibility of fermented product of palm kernel cake and rice bran mixture for broiler. Jurnal Ilmu Dan Teknologi Peternakan, 1(3):167-172.

Suprijatna, E., dan Natawihardja, D. 2014. Pertumbuhan organ reproduksi ayam ras petelur dan dampaknya terhadap performans produksi telur akibat pemberian ransum dengan taraf protein berbeda saat periode pertumbuhan. JITV, 19(3):260-267.

Tamzil, M. H. 2014. Stres panas pada unggas: metabolisme, akibat dan upaya penanggulangannya. Wartazoa, 24(2):57-66.

Widianto, B., Prayogi, H. S., dan Nuryadi, N. 2015. Pengaruh penambahan tepung buah mengkudu (Morinda citrifolia L.) dalam pakan terhadap penampilan produksi itik Hibrida. Jurnal Ilmu-Ilmu Peternakan, 25(2):28-35.

Widjastuti, T., dan Kartasudjana, R. 2006. Pengaruh Pembatasan Ransum Dan Implikasinya Terhadap Performa Puyuh Petelur Pada Fase Produksi Pertama [The Effect of Restricted Feeding and Its Implication on the 
Performance of Coturnix-coturnix japonica at the First Production Phase]. Journal of the Indonesian Tropical Animal Agriculture, 31(3): 162-166.

Wulandari, E. C., Murningsih, W., dan Wahyuni, H. I. 2012. Deposisi kalsium dan phosphor pada cangkang telur ayam arab dengan pemberian berbagai level azolla microphylla. Animal Agriculture Journal, 1(1) : 507-520. 